Archived version from NCDOCKS Institutional Repository http://libres.uncg.edu/ir/asu/

\title{
Appalachỉan
}

B O O N E, N O R T H C A R O L I N A

\section{An Exploratory Study Of Expectation-Importance- Performance Analysis With Cultural Tourists In Havana, Cuba}

\author{
By: Carol Kline, Brian Bulla, Heather Rubright, Erin Green, \& Erin Harris
}

\begin{abstract}
Importance-Performance Analysis (IPA) is an efficient method for measuring two dimensions of a person's attitude on a given topic. The current study added a third dimension, Expectation, to determine if an individual's expectation about a cultural tourism experience impacts their rating of that experience's performance. The study, based in Havana, Cuba, gathered impressions from international visitors regarding 30 types of cultural tourism activities and amenities through an intercept survey. Results indicated that many Expectation and Performance scores were correlated. Additionally, some differences arose in Expectations and perceived Performance among varying age groups and length of stay. The use of this new scale (EIPA) would be valuable to local tourism managers as well as tourism researchers wishing to explore expanded uses of IPA, and should be tested in a variety of cultural contexts.
\end{abstract}

Kline, C., Bulla, B., Rubright, H., Green, E., \& Harris, E. (2016). An exploratory study of expectation-importanceperformance analysis with cultural tourists in Havana, Cuba. Tourism and Hospitality Research, 16(1), 19-34. https://doi.org/10.1177/1467358415600207. Publisher version of record available at: http://journals.sagepub.com/ doi/full/10.1177/1467358415600207 


\title{
An exploratory study of expectation- importance-performance analysis with cultural tourists in Havana, Cuba
}

\author{
Carol Kline
}

Hospitality and Tourism Management, Appalachian State University, NC, USA

\section{Brian Bulla}

Forestry and Environmental Sciences, North Carolina State University, NC, USA

\section{Heather Rubright}

Center for Sustainability, East Carolina University, NC, USA

\section{Erin Green}

Center for Sustainability, East Carolina University, NC, USA

\section{Erin Harris}

Center for Sustainability, East Carolina University, NC, USA

\begin{abstract}
Importance-Performance Analysis (IPA) is an efficient method for measuring two dimensions of a person's attitude on a given topic. The current study added a third dimension, Expectation, to determine if an individual's expectation about a cultural tourism experience impacts their rating of that experience's performance. The study, based in Havana, Cuba, gathered impressions from international visitors regarding 30 types of cultural tourism activities and amenities through an intercept survey. Results indicated that many Expectation and Performance scores were correlated. Additionally, some differences arose in Expectations and perceived Performance among varying age groups and length of stay. The use of this new scale (EIPA) would be valuable to local tourism managers as well as tourism researchers wishing to explore expanded uses of IPA, and should be tested in a variety of cultural contexts.
\end{abstract}

\section{Keywords}

Cuba, importance-performance analysis, expectations, cultural tourism

\section{Introduction}

Cuba has relied on tourism to boost its economy since the collapse of the Soviet Union in 1991 (Elliott and Neirotti, 2008). Additionally, within the last three years, Cuba has made a major shift in its economic policies, laying off 500,000 government employees and opening opportunities for a more entrepreneurial economic approach (Central de Trabajadores de Cuba [CTC], 2010). Cuba's economy and society may continue to change, but that change remains uncertain and the timing is most certainly contingent upon the political climate and how open the economy is to entrepreneurship and outside investment (Becherer and Helms, 2011). Even with U.S. President Obama's decision in December of 2014 to begin normalizing relations between Cuba and the U.S, seeing substantive changes to the Cuban economy remains uncertain (Fletcher, 2014). Tourism in Cuba is on

\section{Corresponding author:}

Carol Kline, Hospitality and Tourism Management. Appalachian State University, 4078 Peacock Hall, Boone, NC 28608, USA.

Email: klinecsdappstate.edu 
the brink of entering a renaissance of development as the political structure and state management practices continue to change (Sharpley and Knight, 2009). This research represents an exploratory study on the state of Havana's cultural tourism industry, and employs Importance-performance analysis (IPA) to provide useful and relevant information as tourism grows and further development is considered.

IPA is an efficient method for measuring two dimensions of a person's attitude on a given topic; generally, a consumer is surveyed and asked, "How important is this certain feature" and "How did this feature perform"? (Pritchard and Havitz, 2006). IPA has been used in a variety of product and service settings, tourism and non-tourism, over the last several decades. Within tourism, it has provided useful information for tourism researchers, planners, and managers in their efforts to develop strategic programs and marketing directions.

In this study, the traditional IPA method was modified to include a third dimension, Expectation, which transformed the instrument into an expectationsimportance-performance analysis (EIPA) and was used to investigate cultural tourism activities and amenities in Havana, Cuba. This modified analytical framework is an important development in the process of determining if a person's expectations affect their evaluation of a given experience. The use of the EIPA framework might foster creative new insights for tourism professionals and small-scale operators as they re-evaluate and reconsider their approach to product development, conservation, interpretation, training, marketing and/ or community involvement.
To pursue this analytic angle, demographic information and reflection data about the tourist's visit to Cuba were collected. Gathering and processing this type of information will allow practitioners, planners, and operators to re-examine their target markets as they decide where and how their resources may be more strategically aligned with the experience of tourists. With the current shifting of enterprise policies in Cuba, this information would be beneficial to the myriad of stakeholders in the tourism industry.

\section{Literature review}

\section{Use of IPA in tourism studies}

IPA is a frequently used quantitative approach for rating consumer evaluations and has been for approximately 25 years (Pritchard and Havitz, 2006). By plotting importance and performance scores along $x$ - and $y$-axes, four quadrants are formed revealing areas in which planners and managers may choose to focus their efforts (see Figure 1). IPA has been used in a variety of applications and settings. One of the earliest studies was Martilla and James (1977) employing IPA to increase new car buyers' loyalty to a dealership after purchase by asking customers about the importance and performance aspects of the service department. Since that time, tourism researchers have found IPA useful for developing strategic insights for both destination features as well as services (Pritchard and Havitz, 2006). For example, McArthur (1994) used IPA to examine aspects of a guided nature-based tour, such as the guide's communication skills, cost of the tour,

\begin{tabular}{|l|l|l|}
\hline $\begin{array}{l}\text { High importance/ low } \\
\text { performance } \\
\text { Concentrate here }\end{array}$ & $\begin{array}{l}\text { High importance/ high } \\
\text { performance } \\
\text { Keep up the good work }\end{array}$ \\
\hdashline$\underline{\frac{5}{\varepsilon}}$ & $\begin{array}{l}\text { Low importance/ low } \\
\text { performance } \\
\text { Low priority }\end{array}$ & $\begin{array}{l}\text { Low importance/ high } \\
\text { performance } \\
\text { Possible Overkill }\end{array}$ \\
\hline & Performance \\
\hline
\end{tabular}

Figure 1. Importance-performance grid. 
and interpretation of the environment. The results were included as part of a comprehensive report to aid in policy development for Tasmania's State Forest (McArthur, 1994). Zhang and Chow (2004) also applied IPA to assess the service performance of tour guides as perceived by visitors. In 2008, Smith and Costello employed IPA in their study as a means to assist culinary event organizers in improving customer satisfaction at the 2006 World Championship Barbecue Cooking Contest by asking about various items such as cooking techniques, local foods, and cultural attractions.

In a destination setting, Pritchard and Havitz (2006) utilized IPA for appraisal of a destination's attributes by tourists. Also in 2005, O'Leary and Deegan collected perception data related to specific destination attributes pre- and post-visitation; these data were used to improve Ireland's destination image as perceived by French tourists. Some of the attributes included in their analysis were nightlife, culture, history, environment, welcome and friendly people, and services available. Joppe et al. (2001) incorporated an importance-satisfaction analysis in order to examine visitor perceptions of products and services in Toronto. The results were then used to increase the service value of that destination by recognizing the perceived strengths and weaknesses (Joppe et al., 2001). Recently, IPA has been used in the field of sustainable tourism; Sörensson and Friedrichs (2013) compared the perceptions of international and domestic tourists concerning the importance of environmental and social sustainability factors. This information was used in order to gain a better understanding of the satisfaction of guests from a sustainability perspective with the goal of improving and evaluating these features in the future (Sörensson and Friedrichs, 2013).

Additionally, IPA is often either modified or used in conjunction with other theories in order to provide strategic insights for tourism providers. Huan et al. (2002) used a variation of IPA analysis in the form of action grid analysis (AGA), which replaces the importance and performance aspects with "relevance" and "achievement" (Huan et al., 2002). They employed separate action grids to depict the different perceptions of four national markets to the end of implementing segmented marketing strategies. Bruyere et al. (2002) also applied IPA combined with segmentation of user groups into year-round residents, seasonal residents, and tourists as a way to measure varying consumer satisfaction in regard to recreational opportunities in a parks and recreation setting. Kim et al. (2011) used the modified theory of reasoned action as well as the importanceperormance grid analysis to explore a visitor's intention to revisit an event based on perceived value and satisfaction. The authors state that the results can be useful to for food festival organizers as well as destination marketing organizations in knowing that perceived value is an antecedent of satisfaction, and that intention to revisit is associated with satisfaction and perceived value. For a critical review of earlier studies involving the use of IPA, see Oh (2001). Additionally, Table 1 demonstrates some of the key ways in which IPA has been used in hospitality, recreation, and tourism studies over the last 25 years.

\section{Expectations studies within hospitality and tourism}

Research involving the expectations of consumers has been conducted in a variety of fields, including tourism, and insights from studies have long fueled and altered both marketing and advertising campaigns. The addition of the expectation dimension to the IPA framework has the potential to yield pertinent information for better understanding the relationships between expectations, importance, and performance of tourist/consumers. Customer expectations can be thought of as beliefs about a product that serve as a reference point against which performance is evaluated ( $\mathrm{Li}$ et al., 2011). Additionally, expectations can be considered a comparative judgment in which satisfaction increases as the performance/expectation ratio increases ( $\mathrm{Li}$ et al., 2011).

Antun et al. (2010) used a DinEX (diner expectations) scale within the hospitality and service sectors in order to examine the expectations and importance for restaurant patrons. Additionally, Hudson et al. (2004) utilized IPA and SERVQUAL and SERVPERF for the purpose of studying service quality in tour operations. SERVQUAL and SERFPERF are both scales designed to measure elements of service quality (Cronin and Taylor, 1992; Parasuraman et al., 1988); however, SERVQUAL measures a customer's perception as well as their expectations of service quality performance, while SERVPERF is a performance-base measurement only. Hudson et al., 2004 recorded the difference between consumers' expectations and perceptions of service elements of a tour operator. Customers were asked prior to a trip to rate expectations and importance; after the trip, the respondents were asked about the performance of these previous items. The results indicated that there were no significant statistical differences between the service quality approaches of IPA, SERVQUAL, and SERPERF (Hudson et al., 2004).

Research has also been conducted on the expectations of various groups of tourists. Andereck et al. (2012: 130) examined experience expectations and 


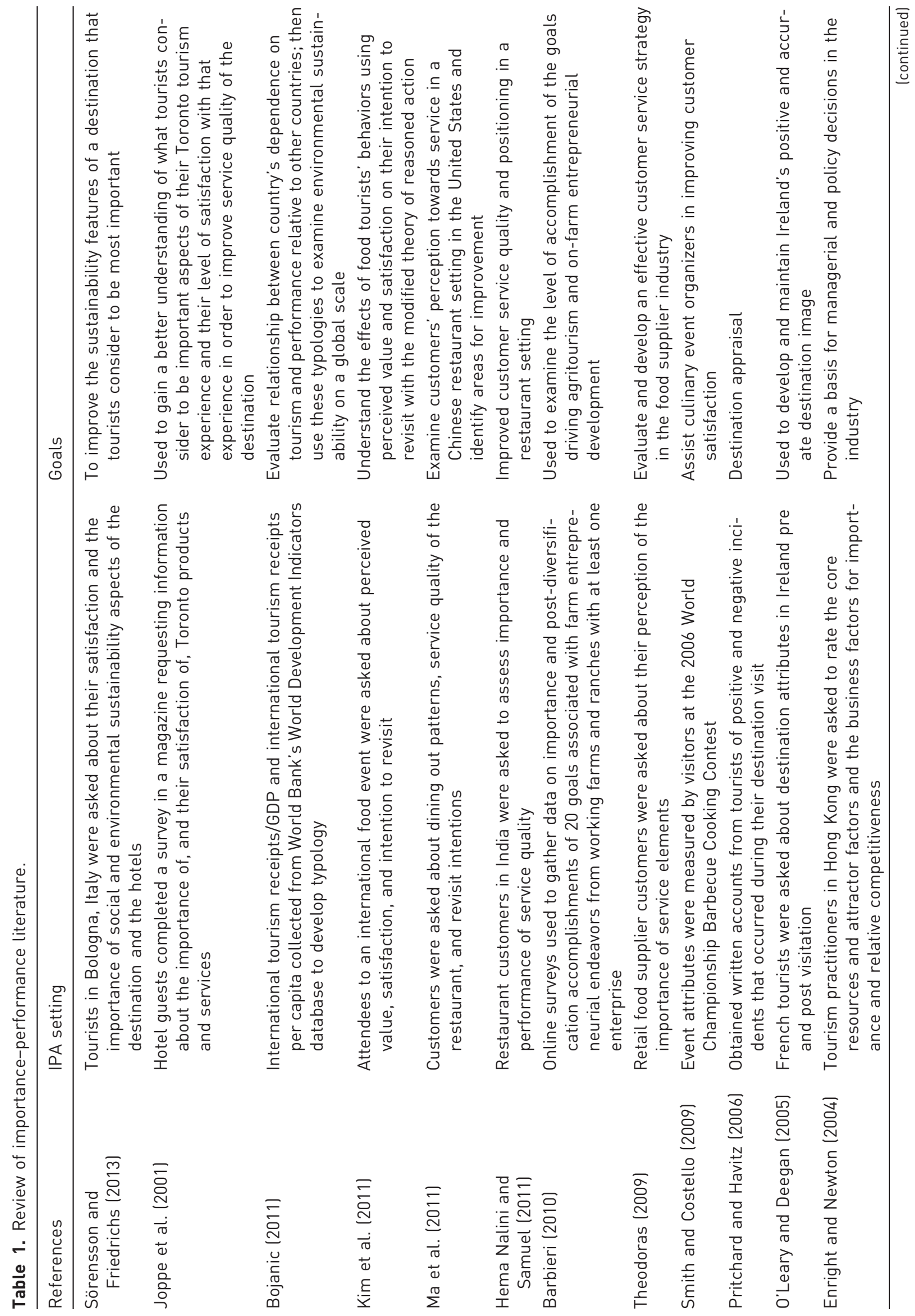




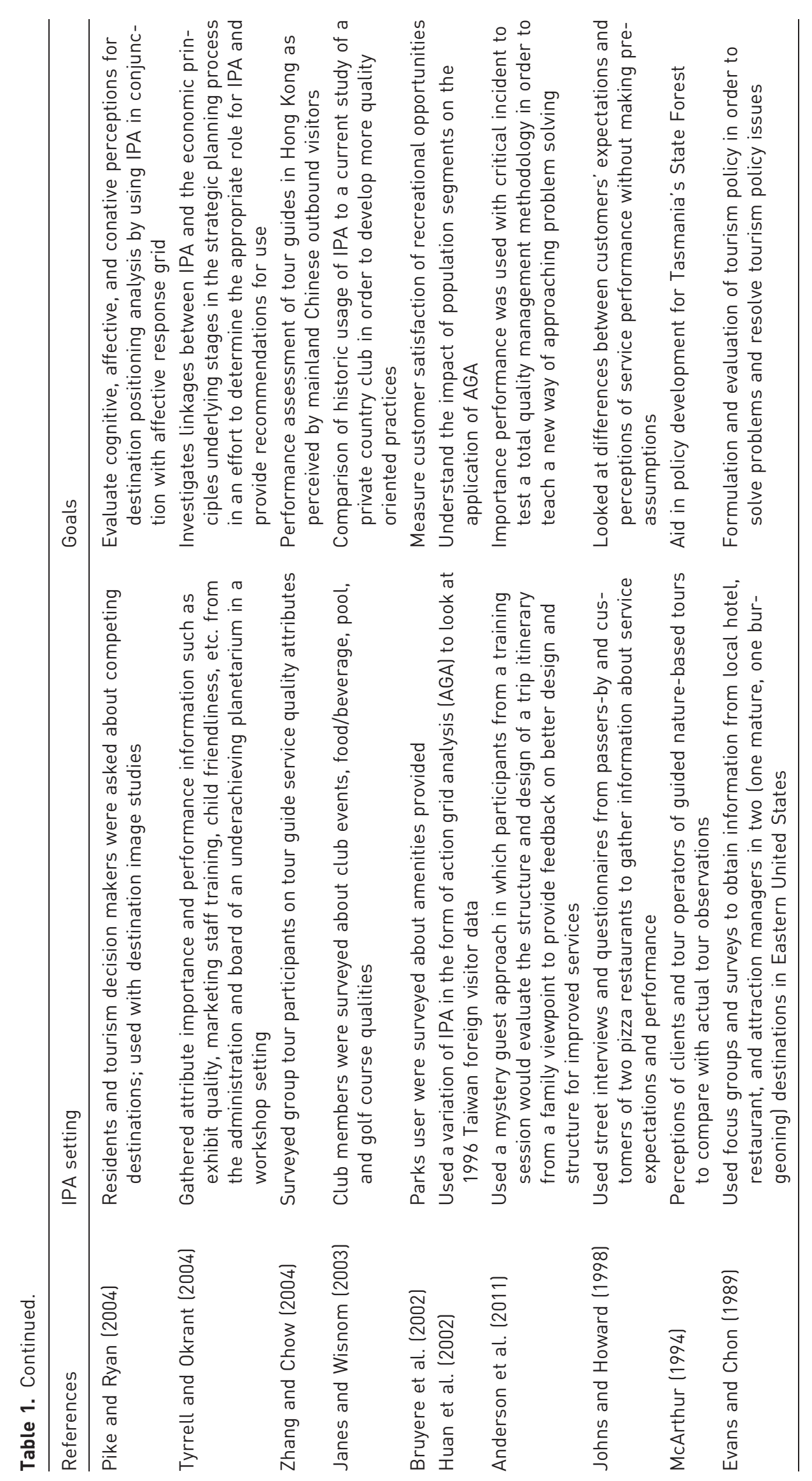


preferences of volunteer tourists in the context of expectancy theory, "which suggests that a travel experience that meets or exceeds tourists' expectations will be viewed positively." Andereck et al. (2012) explored pre-trip experience expectations, activity participation expectations, and differing volunteer tourist expectations in order to more accurately match the volunteer tourists with an experience that suits them as well as the community. In a similar tourist context, Correia et al. (2009) utilized expectancy value theory to look at the motivations, expectations, and perceptions of golf tourists in order to explore destination image. The expectations of Chinese tourists' regarding outbound travel products (accommodations, food and restaurants, tour guides and itineraries, entertainment and activities, and transportation) within the USA have also been studied ( $\mathrm{Li}$ et al., 2011) and found the study group had particular amenity and service expectations.

This study seeks to build off of the recognized history of IPA research to explore the measurement of expectations in relationship to an IPA of cultural tourism attractions and amenities (CTAA) in Havana, Cuba, to determine if expectations add substantive information to the understanding of visitor experiences. The specific research questions in this study are:

1. Is there a relationship between visitors' ratings of expectations, importance and performance of CTAA?

2. Do expectations of CTAA differ among Havana tourists?

3. Are the CTAA of Havana perceived differently among various groups of tourists?

\section{Methods}

\section{Instrument development}

The survey instrument was based on a variety of literature from tourism, agritourism, recreation, culinary, urban design, and museum management disciplines and reflects the major activities and aspects of cultural tourism (Table 2). Items were selected to represent a range of cultural attractions and amenities found in and around an urban center. Reviewing the IPA literature relative to destinations revealed similarities within the lists. The items that were common across instruments, as well as unique items that would apply to Havana, were included on the survey. Participants were asked to consider a series of CTAA items and then rate their expectations of, the importance of, and the performance of those items on a 6-point scale. There were five possible response options plus an additional option if the participant was unsure (Table 3). A 6-point scale has been found to have high reliability without overwhelming the participant with too many choices (Chomeya, 2010; Green and Rao, 1970).

The instrument also included demographic questions including gender, year born, nationality, and country of current residence. Travel behavior questions were also asked such as their length of stay in Cuba, the purpose of their trip, and what activities the participant took part in during their trip. The instrument was translated and made available in English, Spanish, French, German, and Russian. Translation of the survey instrument was cross-checked by a native speaker of the five languages and the instrument was modified to incorporate specific feedback. Field surveyors fluent in each of the languages were utilized as part of the data collection team.

\section{Data collection and analysis}

The population for this study was tourists visiting Havana, Cuba. Over a period of nine days in July 2012, members of the data collection team would approach a tourist, explain the purpose of the study, ask for his/her participation, and determine the tourist's language preference; the survey was offered in English, Spanish, Russian, German, and French. Members of the research team worked alone or in pairs and varied the location (hotel lobbies, restaurants, attractions) as well as the time of day of data collection (morning, afternoon, and evening). Care was taken to ensure that only one representative from each household participated in the study, and groups of different sizes were approached albeit not by a structured protocol. Participants were provided a paper copy of the survey in their preferred language and completed the survey themselves. Surveys were primarily collected in Havana (days 3, 4, 5, 10, and 11 of a 12-day trip); however, $10 \%$ were also collected in Vinales Valley (days 6, 7, and 8) and Varadero (day 9) if tourists were encountered that had spent time in Havana; the variation in location was dictated by the pre-arranged agenda of the trip itself. After data collection, the surveys were compiled and entered into a spreadsheet as a form of backup for the paper-based surveys for safe keeping and during over-seas travel. Data analysis for the study was conducted in SPSS 20.0 once the research team returned home. This study used Pearson's correlation to assess the bivariate associations between Expectation, Importance, and Performance, and T-tests and ANOVA to explore differences between groups.

\section{Results}

The study yielded 66 usable surveys, almost equally split between male (51.5\%) and female (48.5\%) 
Table 2. Instrument items and sources.

\begin{tabular}{|c|c|}
\hline EIPA item & Source \\
\hline Authentic cafes/restaurants & Pike and Ryan (2004) \\
\hline Availability of local art for purchase & Milne et al. (1995) \\
\hline $\begin{array}{l}\text { Availability of local goods for purchase (i.e. cigars, } \\
\text { rum, beer, liquors, etc.) }\end{array}$ & $\begin{array}{l}\text { Scher (2011); Sánchez-Cañizares } \\
\text { and López-Guzmán (2012) }\end{array}$ \\
\hline $\begin{array}{l}\text { Availability of participatory experiences (e.g. dance lessons, } \\
\text { art classes) }\end{array}$ & Argyriadis (2008) \\
\hline Cuban fortresses & Colantonio and Potter (2006) \\
\hline Cultural music performances & Enright and Newton (2004) \\
\hline Experiencing life along the Malecon & Colantonio and Potter (2006) \\
\hline Friendliness of local people/ hospitality of local people & Henthorne et al. (2009); Evans and Chon (1989) \\
\hline Guides with good communication skills & Lin (2009) \\
\hline Historic sites & Pritchard and Havitz (2006) \\
\hline Interesting architecture & Enright and Newton (2004) \\
\hline Knowledgeable guides & McArthur (1994) \\
\hline Lots to see and do & Pike and Ryan (2004) \\
\hline Museums and galleries & Enright and Newton (2004) \\
\hline Nightlife & Enright and Newton (2004) \\
\hline Opportunities to learn about political history & Alhemoud and Armstrong (1996) \\
\hline Opportunities to meet and interact with local Cubans & Loker-Murphy and Pearce (1995) \\
\hline Opportunities to view the sea & Echtner and Ritchie (1993) \\
\hline Outdoor recreation opportunities & Kline (2007) \\
\hline Presence of live music in restaurants & Johns and Howard (1998) \\
\hline Proximity to farm experiences & Pearce (1990) \\
\hline Public art & Mccarthy (2006) \\
\hline Public music and performances & Enright and Newton (2004) \\
\hline Revolution artifacts/sites & Huan et al. (2002) \\
\hline Service in restaurants & Henthorne et al. (2009) \\
\hline Special events and festivals & Enright and Newton (2004) and Kline (2007) \\
\hline Sporting events & Sugden (2007) \\
\hline Variety of local cuisine & Sánchez-Cañizares and López-Guzmán (2012) \\
\hline View into the local way of life & Enright and Newton, 2004 \\
\hline Well-designed wayfaring signs & Lin (2009) \\
\hline
\end{tabular}

Table 3. Scale explanation.

\begin{tabular}{llll}
\hline Rating Scale & Level of expectations & Importance & Performance \\
\hline 5 & Very high expectations & High importance & Outstanding performance \\
4 & High expectations & Important & Good performance \\
3 & Moderate expectations & Moderate importance & Moderate performance \\
2 & Low expectations & Low importance & Low performance \\
1 & Very low expectations & Not important & Unsatisfying performance \\
0 & Unsure/do not know & Unsure/do not know & Unsure/do not know \\
\hline
\end{tabular}

respondents (Table 4). Over half $(54.8 \%)$ of the sample was younger than 40 . There were many nationalities represented in the sample, with British (15.4\%), Canadian, and German (12.3\% each), and Dutch
$(10.8 \%)$ being the highest proportion. Most of the respondents $(75.4 \%)$ were visiting Cuba for a minimum of two weeks. Nearly half $(46.2 \%)$ were traveling with their spouse/partner while another $46.2 \%$ 
Table 4. Demographic profile of participants.

\begin{tabular}{|c|c|}
\hline Variable & $\begin{array}{l}\text { Percentage } \\
(\%)\end{array}$ \\
\hline \multicolumn{2}{|l|}{ Gender $(N=66)$} \\
\hline Female & 48.5 \\
\hline Male & 51.5 \\
\hline \multicolumn{2}{|l|}{ Age $(N=62)$} \\
\hline 19 - 29 years old & 27.4 \\
\hline 30 - 39 years old & 27.4 \\
\hline $40-49$ years old & 13.6 \\
\hline 50 - 59 years old & 19.7 \\
\hline $60+$ and older & 9.1 \\
\hline \multicolumn{2}{|l|}{ Nationality $(N=65)$} \\
\hline British & 15.4 \\
\hline Canadian & 12.3 \\
\hline German & 12.3 \\
\hline Dutch & 10.8 \\
\hline American & 9.2 \\
\hline Cuban & 6.2 \\
\hline French & 6.2 \\
\hline Spanish & 4.6 \\
\hline Singaporean & 3.1 \\
\hline Welsh & 3.1 \\
\hline Other & 16.9 \\
\hline \multicolumn{2}{|c|}{ Country of Residence $(N=66)$} \\
\hline Netherlands & 13.6 \\
\hline UK & 13.6 \\
\hline USA & 13.6 \\
\hline Canadian & 12.1 \\
\hline Germany & 9.1 \\
\hline France & 6.1 \\
\hline Spain & 4.5 \\
\hline Ireland & 3.0 \\
\hline Switzerland & 3.0 \\
\hline Other & 21.2 \\
\hline
\end{tabular}

reported traveling with a colleague (Table 5). Other respondents noted traveling with their family $(29.2 \%)$, a tour group (29.2\%), friends $(24.6 \%)$, or solo $(24.6 \%)$. Respondents were encouraged to select multiple categories of traveling companions, and therefore the percentages total more than $100 \%$. The six most common CTAA activities reported were: Experiencing local food and drink (81.8\%), Nightlife (clubs, bars, shows) (78.8\%), Visiting historic sites or attractions (74.2\%), Visiting arts and cultural attractions (57.6\%), Eating at a paladar, a private restaurant sometimes found in a resident's home (56.1\%), and Beach activities (54.5\%).
Table 5. Travel Profile of Participants.

\begin{tabular}{|c|c|}
\hline Variable & $\begin{array}{l}\text { Percentage } \\
(\%)\end{array}$ \\
\hline \multicolumn{2}{|l|}{ Length of Stay $(N=65)$} \\
\hline One week or less & 24.6 \\
\hline Two weeks & 46.2 \\
\hline Three or more weeks & 29.2 \\
\hline \multicolumn{2}{|l|}{ Traveling Companions $(N=66)^{*}$} \\
\hline Individual & 24.6 \\
\hline Spouse/ Partner & $46.2 \%$ \\
\hline Family & 29.2 \\
\hline Friends & 24.6 \\
\hline Colleague & 46.2 \\
\hline Tour group & 29.2 \\
\hline \multicolumn{2}{|l|}{ Activities $(N=66)^{*}$} \\
\hline Experiencing local food and drink & 81.8 \\
\hline Nightlife (clubs, bars, shows) & 78.8 \\
\hline Visiting historic sites or attractions & 74.2 \\
\hline $\begin{array}{l}\text { Visiting arts and cultural attractions } \\
\text { (museums, galleries) }\end{array}$ & 57.6 \\
\hline Eating at a paladar & 56.1 \\
\hline Beach activities & 54.5 \\
\hline Educational activities or tours & 42.4 \\
\hline $\begin{array}{l}\text { Nature-based recreation (scuba diving, } \\
\text { fishing, hiking, cycling) }\end{array}$ & 42.4 \\
\hline Shopping & 39.4 \\
\hline Staying in a casa particulares & 33.3 \\
\hline $\begin{array}{l}\text { Participatory experiences (i.e. dance les- } \\
\text { sons, cooking classes) }\end{array}$ & 28.8 \\
\hline Attend a community festival or celebration & 24.2 \\
\hline Attending a meeting/ convention & 13.6 \\
\hline $\begin{array}{l}\text { Conducting research or activities related } \\
\text { to science }\end{array}$ & 13.6 \\
\hline Attending a sports event & 10.6 \\
\hline Business dealings & 10.6 \\
\hline Studying for class credit & 4.5 \\
\hline Volunteering & 4.5 \\
\hline Mission Work & 0.0 \\
\hline
\end{tabular}

*Percentages add up to more than $100 \%$ due to respondents' ability to select more than one.

\section{Expectation, importance, and performance ratings}

Respondents were asked to provide their level of expectation, an estimation of importance, and their perception of performance for thirty different CTAA in Havana. Table 6 displays the mean scores for each in descending order of performance scores. The CTAA with the greatest mean Expectation scores 
Table 6. Expectation, importance, and performance mean ratings for Havana's cultural attractions and amenities $(n=66)$.

\begin{tabular}{|c|c|c|c|}
\hline Cultural attraction/amenity & $E$ & 1 & $\mathrm{P}$ \\
\hline Interesting architecture & 4.21 & 3.94 & 4.40 \\
\hline Friendliness/hospitality of local people & 4.03 & 4.32 & 4.28 \\
\hline Availability of local goods for purchase (cigars, rum, beer) & 4.11 & 3.62 & 4.23 \\
\hline View into the local way of life & 4.03 & 4.15 & 4.16 \\
\hline Opportunity to meet and interact with Cubans & 3.89 & 4.03 & 4.14 \\
\hline Opportunities to view the sea & 4.07 & 3.77 & 4.10 \\
\hline Lots to see and do (attractions or landmarks) & 4.00 & 4.13 & 4.04 \\
\hline Historic sites & 3.85 & 3.55 & 3.98 \\
\hline Presence of live music in restaurants & 3.74 & 3.46 & 3.93 \\
\hline Public music and performances & 3.78 & 3.44 & 3.89 \\
\hline Cultural music performances (symphony, ballet, opera) & 3.65 & 3.16 & 3.85 \\
\hline Outdoor recreation opportunities & 3.39 & 3.00 & 3.79 \\
\hline Opportunities to learn about political history & 3.75 & 3.67 & 3.73 \\
\hline Guides with good communication skills & 3.37 & 3.57 & 3.72 \\
\hline Availability of local art for purchase & 3.27 & 2.88 & 3.72 \\
\hline Nightlife/ things to do at night & 3.90 & 3.55 & 3.69 \\
\hline Experiencing life along the Malecón & 3.47 & 3.24 & 3.67 \\
\hline Knowledgeable guides & 3.43 & 3.47 & 3.66 \\
\hline Revolution artifacts/ sites & 3.98 & 3.47 & 3.63 \\
\hline Museums and galleries & 3.43 & 3.30 & 3.62 \\
\hline Public art & 3.25 & 3.15 & 3.55 \\
\hline Authentic cafes/restaurants & 3.63 & 3.93 & 3.47 \\
\hline Cuban fortresses & 3.31 & 2.91 & 3.35 \\
\hline Service in restaurants & 3.34 & 3.60 & 3.34 \\
\hline Variety of local cuisine & 3.25 & 3.73 & 3.20 \\
\hline Availability of participatory experiences (dance lessons) & 3.19 & 2.88 & 3.17 \\
\hline Sporting events & 2.47 & 2.13 & 3.09 \\
\hline Special events and festivals & 3.41 & 2.74 & 3.06 \\
\hline Well-designed wayfaring/ wayfinding signs & 2.78 & 3.28 & 2.61 \\
\hline Proximity to farm experiences & 2.26 & 2.00 & 2.61 \\
\hline
\end{tabular}

Note: $5=$ Very high expectations, high importance, outstanding performance; $4=$ high expectations, important, good performance; $3=$ moderate expectations, moderate importance, moderate performance; $2=$ low expectations, low importance, low performance; $1=$ very low expectations, not important; unsatisfying performance. If the respondent checked "unsure/ do not know," their response had no numerical value and therefore was not calculated as part of the average.

(4 or above) were: Opportunities to learn about political history, Interesting architecture, Availability of local goods for purchase (cigars, rum, beer), Opportunities to view the sea, Friendliness/ Hospitality of local people, View into the local way of life, and Lots to see and do. The CTAA with the greatest mean Importance scores (4 or above) were: Friendliness/ Hospitality of local people, View into the local way of life, Lots to see and do, and Opportunity to meet and interact with Cubans. The CTAA with the greatest mean Performance scores (4 or above) were: Interesting architecture, Friendliness/ Hospitality of local people, Availability of local goods for purchase, View into the local way of life, Opportunity to meet and interact with Cubans, Opportunities to view the sea, and Lots to see and do.

\section{Test results}

To address the first research question, Is there a relationship between visitors' ratings of expectations, importance and performance of CTAA?, Pearson's correlation was used to analyze the relationship among the three dimensions. While a sample size of 66 is small for computation of bivariate correlation, Bonett and Wright (2000) determined that for a desired confidence interval of .3, using a planning estimate of .70 for Pearson's 
Table 7. Correlations between Expectation, Importance, and Performance Ratings for Havana's Cultural Attractions and Amenities $(n=66)$.

\begin{tabular}{|c|c|c|c|}
\hline Cultural attraction/amenity & $E \& I$ & $I \& P$ & $E \& P$ \\
\hline Proximity to farm experiences & $.782^{* *}$ & $.597^{* *}$ & $.664^{* *}$ \\
\hline Sporting events & $.870^{* *}$ & $.721^{* *}$ & $.618^{* *}$ \\
\hline Availability of local goods for purchase (cigars, rum, beer) & $.492^{* *}$ & $.257^{*}$ & $.527^{* *}$ \\
\hline Special events and festivals & $.709 * *$ & $.726^{* *}$ & $.503^{* *}$ \\
\hline Opportunities to view the sea & $.676^{* *}$ & $.486^{* *}$ & $.488^{* *}$ \\
\hline Historic sites & $.662^{* *}$ & $.582^{* *}$ & $.484^{* *}$ \\
\hline Authentic cafes/restaurants & $.584^{* *}$ & $.358 * *$ & $.464^{* *}$ \\
\hline Opportunities to learn about political history & $.658^{* *}$ & $.463^{* *}$ & $.441^{* *}$ \\
\hline Knowledgeable guides & $.618^{* *}$ & $.616^{* *}$ & $.430^{* *}$ \\
\hline Public art & $.623 * *$ & $.327^{*}$ & $.425^{* *}$ \\
\hline Revolution artifacts/ sites & $.715^{* *}$ & $.320^{*}$ & $.417^{* *}$ \\
\hline Experiencing life along the Malecón & $.852^{* *}$ & $.448 * *$ & $.383^{* *}$ \\
\hline Opportunity to meet and interact with Cubans & $.592^{* *}$ & $.277^{*}$ & $.357^{* *}$ \\
\hline Cuban fortresses & $.778^{* *}$ & $.373^{* *}$ & $.340^{*}$ \\
\hline Availability of local art for purchase & $.582^{* *}$ & 0.084 & $.327 *$ \\
\hline Museums and galleries & $.675^{* *}$ & 0.188 & $.322 *$ \\
\hline Interesting architecture & $.458^{* *}$ & 0.146 & $.300^{*}$ \\
\hline Guides with good communication skills & $.631 * *$ & $.563^{* *}$ & 0.265 \\
\hline Presence of live music in restaurants & $.591 * *$ & $.353^{* *}$ & 0.229 \\
\hline View into the local way of life & $.576^{* *}$ & $.524^{* *}$ & 0.224 \\
\hline Well-designed wayfaring/ wayfinding signs & $.498 * *$ & -0.76 & 0.206 \\
\hline Nightlife/ things to do at night & $.735^{* *}$ & $.266^{*}$ & 0.203 \\
\hline Availability of participatory experiences (dance lessons) & $.670 * *$ & $.361^{*}$ & 0.196 \\
\hline Cultural music performances (symphony, ballet, opera) & $.530 * *$ & 0.282 & 0.19 \\
\hline Variety of local cuisine & $.650 * *$ & 0.126 & 0.159 \\
\hline Service in restaurants & $.528 * *$ & $.268^{*}$ & 0.13 \\
\hline Lots to see and do (attractions or landmarks) & $.680 * *$ & 0.118 & 0.12 \\
\hline Outdoor recreation opportunities & $.684^{* *}$ & 0.256 & 0.116 \\
\hline Friendliness / Hospitality of local people & $.483^{*}$ & $.276^{*}$ & 0.115 \\
\hline Public music and performances & $.588 * *$ & $.294^{*}$ & -0.15 \\
\hline
\end{tabular}

$* p<.05$.

$*_{*}^{* *} p<.01$.

correlation at the $p<.05$ level, a sample size of 49 is needed. Other estimates using a small sample size denote (1) a sample of 64 will provide $80 \%$ power to discover a moderate correlation $(r=.30 ; p<.05$; Power Analysis for Correlations, n.d.) and (2) a sample of 85 will provide $80 \%$ power and a medium effect size (Sample Size for Bivariate Correlation, n.d.). Therefore, because of the small sample size and the introduction of the new Expectation dimension, this study is considered exploratory and test results should be interpreted with caution.

The strongest correlations between Expectation and Importance dimensions ( $r=.7$ or above) were in Sporting events, Experiencing life along the Malecón, Proximity to farm experiences, Cuban fortresses,
Nightlifel things to do at night (Table 7), Revolution artifacts/ sites, and Special events and festivals. The strongest correlations between Importance and Performance dimensions ( $r=.5$ or above) were in Special events and festivals, Sporting events, Knowledgeable guides, Proximity to farm experiences, Historic sites, Guides with good communication skills, and View into the local way of life. The strongest correlations between Expectation and Performance dimensions ( $r=.5$ or above) were in Proximity to farm experiences, Sporting events, Availability of local goods for purchase, and Special events and festivals.

Interestingly, the majority of CTAA demonstrated a strong correlation between Expectation and Importance (Table 7); there are several possible reasons for this 
result. First, the more important a destination element is to a traveler, the more they may investigate it prior to the trip, thereby elevating their expectations. This is somewhat intuitive in the sense that if a person is selecting the location because of the presence of this element, then their anticipation might drive a higher expectation, which might provide a partial explanation for this result. This does not take into account those CTAA that are important (high importance) to an individual, but which the destination cannot deliver (low performance). There also exists the possibility for 'wishful thinking' in that if a destination attribute is important to an individual in general (i.e. it is important to him to try local cuisine anywhere he travels), then perhaps his hope for this translates into an expectation that the local cuisine will be good in any given destination. The correlation between low expectation and low importance may be explained by apathy on the part of the tourist. If a tourist did not feel that a particular attraction were important to him (e.g. Revolution artifacts), he may not care enough to look into this element at the destination to form an opinion about what to expect. Additionally, previous experience, which was not measured in the current study, could influence a tourist's expectation, perceived importance, and perceived performance with a destination's amenities. While the majority of correlations between Expectation and Importance were moderately strong or strong, about half of the correlations between Expectation and Performance and the correlations between Importance and Performance were low indicating a weak relationship. Further inquiry into the lack of correlation on these elements, in Cuba and otherwise, may yield valuable information to attraction and destination managers.

To address the second research question, Do expectations of CTAA differ among Havana tourists?, a $t$-test was run to examine differences between males and females, and an ANOVA was used to test differences in age groups and length of stay. The 40-49, 50-59 and $60+$ age groups were combined to create more equal group sizes. The length of stay categories of 3 , 4 , and 6 weeks were combined for the same reason. Nationality and current residence were not included in the analyses due to the small number in each group. Companion was not included because respondents could check multiple groups.

Four significant differences were found between males and females, and for each the women held higher expectations of the CTAA: Availability of participatory experiences males $(\mathrm{M}=2.57, \mathrm{SD}=1.40)$ females $\quad(M=3.62, \quad S D=1.24) ; \quad \mathrm{t}(40)=-2.58$, $p<.05 ;$ Special events and festivals $(\mathrm{M}=2.83$, $\mathrm{SD}=1.04)$ females $(\mathrm{M}=3.80, \mathrm{SD}=1.16) ; \mathrm{t}(39)=$ $-2.77, p<.05 ;$ Museums and galleries $(\mathrm{M}=3.10$,
$\mathrm{SD}=1.19)$ females $(\mathrm{M}=3.71, \mathrm{SD}=1.05) ; \mathrm{t}(59)=$ $-2.14, \mathrm{p}<.05$; Revolution artifacts/ sites $(\mathrm{M}=3.69$, $\mathrm{SD}=1.07) \quad$ females $\quad(\mathrm{M}=4.28, \quad \mathrm{SD}=0.88)$; $\mathrm{t}(56)=-2.28, p<.05$.

Within age group, three statistically significant differences were found in the Opportunities to view the sea $[\mathrm{F}(2,59)=3.313, p<.05]$, Presence of live music in restaurants $[\mathrm{F}(2,56)=5.597, p<.01]$, and Opportunity to meet and interact with Cubans $[\mathrm{F}(2,62)=8.576$, $p<.01]$. Post hoc comparisons using the Tukey HSD test indicated the $40+$ group $(n=24, M=3.63$, $\mathrm{SD}=1.313)$ felt there were less Opportunities to view the sea than the 20- to 29-year-old group ( $n=21$, $\mathrm{M}=4.38, \mathrm{SD}=0.805)$ or the 30 - to 39-year-old group $(n=17, M=4.35, \mathrm{SD}=1.115)$. However, the 30- to 39-year-old group had a less positive impression of Presence of live music in restaurants $(n=16, M=3.00$, $\mathrm{SD}=1.211)$ and Opportunity to meet and interact with Cubans $(n=17, \mathrm{M}=3.06, \mathrm{SD}=1.008)$ than their older $(n=23, \mathrm{M}=4.04, \mathrm{SD}=0.928$ for Presence of live music in restaurants; $n=27, \quad M=4.04$, $\mathrm{SD}=1.126$ for Opportunity to meet and interact with Cubans) or younger counterparts $(n=20, M=3.90$, $\mathrm{SD}=0.912$ for Presence of live music in restaurants; $n=21, \mathrm{M}=4.38, \mathrm{SD}=0.740$ for Opportunity to meet and interact with Cubans).

In the investigation of differences among visitors who had varying lengths of stay, there was one statistically significant difference within View into the local way of life $[\mathrm{F}(2,60)=10.456, p<.01]$. Visitors who stayed the longest, Three or more weeks $(n=19$, $\mathrm{M}=4.68, \mathrm{SD}=0.582$ ) had the most positive impression, followed by those who stayed Between one and two weeks $(n=30, \mathrm{M}=3.97, \mathrm{SD}=0.964)$ which was higher than those who stayed One week or less $(n=14, \mathrm{M}=3.29, \mathrm{SD}=0.994)$. It makes intuitive sense that the longer the stay, the more opportunities (or even desire) a visitor may have for viewing local life.

And finally, to address the third research question Are the CTAA of Havana perceived differently among various groups of tourists?, a t-test was run to examine differences between males and females, and an ANOVA was used to test differences in age groups and length of stay. The age groups and length of stay groups were combined as above to create more equal group sizes. There were no significant differences in gender or age groups. However, within the length of stay variable, statistically significant differences were evident in the Guides with good communication skills $[\mathrm{F}(2,58)=4.591, p<.05]$ and Lots to see and do (attractions or landmarks) variables $[\mathrm{F}(2,47)=3.294$, $p<.05]$. Post hoc comparisons using the Tukey HSD test indicated for the Lots to see and do variable, the mean score for respondents visiting Between one and 
two weeks $(\mathrm{M}=4.31, \mathrm{SD}=0.604)$ was higher than visitors staying Three or more weeks ( $\mathrm{M}=4.06$, $\mathrm{SD}=0.873)$, and those who stayed One week or less $(\mathrm{M}=3.57, \mathrm{SD}=0.852)$. Post-hoc comparisons of the Guides with good communication skills showed a slightly different pattern with the mean score for respondents visiting Between one and two weeks $(\mathrm{M}=4.04, \mathrm{SD}=1.055)$ higher than those who stayed One week or less $(\mathrm{M}=3.92, \mathrm{SD}=0.954)$ and Three or more weeks $(\mathrm{M}=3.00, \mathrm{SD}=1.414)$. On these two particular elements of cultural tourism, the group staying between one and two weeks reported a higher perceived performance than visitors staying shorter or longer periods of time.

\section{Discussion}

Sharpley and Knight (2009) stated that Cuban tourism is on the brink of entering a new era of development as the political structure continues to change. Cuba is no longer strictly a place visited for sun, fun, and rum, but instead is being increasingly recognized as a destination with a diversity of authentic and local cultural tourism offerings. Planners and managers have to develop marketing plans for tourism development that provide strategic insights into Cuba for both its unique destination features as well as services (Pritchard and Havitz, 2006). IPA is a tested way to develop these strategies, and this research has added Expectation to the existing IPA tool in order to create a new cultural attraction scale. Research around customer expectation is important because it is seen as a reference point against which performance is evaluated (Li et al., 2011).

Adding Expectation to an IPA scale adds substantive information to the understanding of visitor experience and provides a broader perspective on consumer perception. Marketers can use Expectation to understand how their destination is perceived, which in turn will help marketers appreciate if they are sending the right message to potential tourists. If not, marketers can regroup to determine the best strategy for rebranding their destination. Additionally, destination managers in Cuba could use the findings on destination strengths and destination challenges to substantiate the need and resources for product development or renovation. Figure 2 proposes a variation on the standard IPA grid by crossing Expectation and Performance. Particularly critical to destination management, a high expectation and low performance can create disappointment and dissatisfaction, and would inevitably need an intervention of 'damage control' to rectify a tourist's impression; however, a manager would need to learn of this disappointment from the visitor in order to be able to act on it. Additionally, in the areas of low expectation and high performance, a feeling of 'pleasant surprise' would ensue. The destination elements that consistently fall within this quadrant should perhaps be emphasized more in marketing campaigns in order to attract new niche markets.

The addition of Expectation opens the door to new research inquiry as well. What portion of expectations are formed through previous experience, information received from acquaintances, media and social media,

\begin{tabular}{|c|c|c|}
\hline \multirow{3}{*}{ 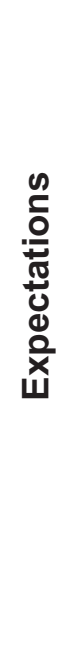 } & $\begin{array}{l}\text { High expectation/ low } \\
\text { performance } \\
\text { Major disappointment/ high } \\
\text { priority to remedy } \\
\text { performance or curb } \\
\text { expectation }\end{array}$ & $\begin{array}{l}\text { High expectation/ high } \\
\text { performance } \\
\text { Keep up the good work }\end{array}$ \\
\hline & $\begin{array}{l}\text { Low expectation/ low } \\
\text { performance } \\
\text { Low priority }\end{array}$ & $\begin{array}{l}\text { Low expectation/ high } \\
\text { performance } \\
\text { A pleasant surprise/ possible } \\
\text { item to market further }\end{array}$ \\
\hline & & \\
\hline
\end{tabular}

Figure 2. Expectations-performance grid. 
marketing messages, assumptions, and other factors? While the Expectation rating would not provide this knowledge, it is the first step in looking for patterns, statistically significant differences between groups, and comparisons across destinations. We know from scant literature exploring expectations that they differ across individuals, and that expectations are not a monodimensional construct. For example, Andereck et al. (2012) found varying expectations among voluntourists relative to pre-trip services, the level of contact with residents, and the intensity of physical or emotional strains.

This research found a strong correlation between Expectation and Importance on most items items. There are several possible causal explanations for this correlation, which should be explored through future studies, but the value established in this study is that Expectation did merge well with the established IPA framework. Through further studies and careful application, comparing Expectation to Importance and Performance has the potential to provide valuable insights not available previously using IPA. For example, if you know what pleasantly surprised tourists compared to their expectation, then this bit of information becomes a value-added component shedding crucial insight into a tourist's experience. Also, if you know a tourist is not expecting to see something, then you may not need to emphasize marketing those offerings unless a goal is to change traveler expectations and re-branding that aspect of your destination.

On issues regarding visitor management, Cuban tourism marketers should encourage and find a way to enable visitors to stay one to two weeks. Once visitors stay for more than one week and begin approaching two weeks, they start speaking more favorably of their experience on the island and are more likely to become repeat visitors. Shifts in the Cuban tourism experience is evidenced by the fact that many tourists report that having a 'beach experience' or seeing the sea is not necessarily important to them even though they fully expect the sea to be a constant backdrop during their visit. Additionally, tourists 40 years and older often do not realize or consider that there are many opportunities to visit the waterfront areas of Cuba, so marketers might provide information on the various opportunities for beach- or water-related tourism activities in their marketing campaigns specifically targeted to tourists over the age of 40 .

Results also indicated that the longer the tourist stayed, the more opportunities (or even desire) they reported in experiencing local life. Sporting events, proximity to farm experiences, and special events and festivals all have a strong correlation across expectation, importance, and performance of these offerings. This could suggest tourists are specifically seeking out these opportunities in Cuba. Bruyere et al. (2002) advocated for using segmentation along with IPA, for a more targeted approach to market intelligence. Segmenting by gender, age, and length of stay is simply a start, and with a larger sample, future studies can broach nationality, trip purpose, and various psychographics.

Regarding destination strengths, the opportunity to meet and interact with Cubans was a pleasant surprise for many tourists. The recent allowances in the policies regarding private enterprise will undoubtedly allow for increased interactions between tourists and Cubans as more Cubans decide to start their own businesses.

Women had higher expectations of Availability of participatory experiences, Special events and festivals, Museums and galleries, and Revolution artifacts/ sites. Without gathering data on underlying reasons (as Correia et al., 2009 did), it is difficult to know why this difference occurred; however, this seems to be a phenomenon worth exploring. Tourists reported high expectations for seeing unique architecture though it was not necessarily an important factor for them when considering their destination. Also, their high expectations were met by Cuba's offerings of unique architecture. A widely unknown asset of Cuban tourism is the diversity and availability of local goods for purchase. Although the availability of local goods for purchase was neither important nor expected of tourists, it performed well. Knowledgeable guides with good communication skills, historic sites, and views into the local way of life were all important attributes to tourists and each performed well in Cuba. With new information about the expectations, importance and performance of each of these factors, marketers could tailor their messages to potential tourists to create expectations of purchases (tours, souvenirs, experiences around architecture) even before arriving to the island nation (Enright and Newton, 2004; O'Leary and Deegan, 2005; Pike and Ryan, 2004), and direct policy toward product development and restoration (Evans and Chon, 1989).

A challenge felt by respondents revolved around the information available about Cuban politics. Tourists expected to learn more about Cuban politics when traveling to Cuba but soon realized the political climate is still closed and largely inaccessible to them. While the political climate remains closed, business and entrepreneurial policies are beginning to show signs of market-inspired life. And specifically regarding one age group, 30- to 39-year-olds were not happy with the lack of live music or opportunities to meet and interact with Cubans, so there is opportunity for marketers to adjust product offerings to accommodate this age group. 
While the examination of destination attributes is spatially and culturally contextual, some comparisons can be drawn across locations. For example, Smith and Costello (2009) used IPA to examine satisfaction of culinary products. Their study was conducted in a "cook off" competition setting. This study is relevant as the culinary experience is extremely important in Cuba and in tourism in general. In the current study, Authentic cafes/restaurants, Service in restaurants, and Variety of local cuisine were all rated as Important to the sample, but only earned a Moderate Performance rating. Other researchers (Antun et al., 2010; Hudson et al., 2004) used a version of IPA to examine satisfaction with the service elements of a dining experience, and Joppe et al. (2001) used a version to explore service within a destination. While this study did not explore service in depth, as stated above, Service in restaurants earned a Moderate Performance rating and the Friendliness/ Hospitality of local people earned a High Performance rating. One of the contributions of this study is to go beyond basic products and services to assess other intangible (and tangible) elements of the cultural experience. For example, quality tour guiding is essential to the enhancement of a visitor's experience in any location. However, because Cuban residents and knowledge about Cuban life are largely inaccessible through the Internet and international media, the interpretive experience and personal connection with tour guides becomes even more critical as a part of the tourism product. This aligns with the findings of McArthur (1994) and Zhang and Chow (2004); within the current study, Guides with good communication skills and Knowledgeable guides earned a Moderate Performance rating.

This research is not without its limitations. The results would have been more conclusive with a larger sample size. Also, because this research was specifically focused on Cuba, the findings are probably not generalizable to other destinations; however, the uniqueness of Cuba is worthy of this type of exploratory research especially with the recent thawing of governmental relations between the USA and Cuba. Additionally, there are multiple research opportunities that have emerged from this study. The element of expectation in EIPA should be developed and investigated further. Research using a three-way chi square test could be used on the three elements. Researchers could explore other differences (beyond socio-demographics) in tourists to see how they differ along the EIPA scale. Further research opportunities include exploring reasons for the correlations found or the differences among additional variables. This study could be repeated in different contexts (e.g. island vs. socialist nation vs. economic status), or with different tourist segments similar to Bruyere et al.'s (2002) research.
Li et al. (2011) stated that expectations are a reference point against which performance is evaluated, and suggested that satisfaction increases as the performance/expectation ratio increases. Additional research in this area would yield prominent insights into the link between destination marketing and destination management. The current study contributes to this need by introducing an inclusive set of items measuring cultural attractions and amenities.

\section{Conclusion}

Cuba is a compelling destination and presents a very persuasive allure for researchers and tourists alike. Conducting research in Cuba is not an easy undertaking for political, logistical, and economic reasons, yet doing so is rewarding because of its unique geopolitical context. By broadening the established IPA framework to include Expectations, this study expands the process of exploring how tourists experience Cuba and Cuban culture. Through these exploratory findings and strong correlations between the expectations, importance, and performance of tourists, destination marketers and CTAA operators in Cuba and those servicing Cuba might each be able to more strategically allocate their efforts and resources. Key insights and marginal adjustments tailored to the EIPA could prove critical to enhancing the tourism experience and market for the producer as well as consumer in this country beginning to open itself to a market economy.

\section{References}

Alhemoud AM and Armstrong EG (1996) Image of tourism attractions in Kuwait. Fournal of Travel Research 34(4): 76-80.

Andereck K, McGehee N, Lee S, et al (2012) Experience expectations of prospective volunteer tourists. Fournal of Travel Research 51(2): 130-141.

Anderson D, Groves D, Lengfelder J, et al. (2011) A research approach to training: A case study of mystery guest methodology. International Fournal of Contemporary Hospitality Management 13(2): 93-102.

Antun JM, Frash Jr RE, Costen W, et al. (2010) Accurately assessing expectations most important to restaurant patrons: the creation of the DinEX Scale. Fournal of Foodservice Business Research 13(4): 360-379.

Argyriadis K (2008) Speculators and santuristas: The development of Afro-Cuban cultural tourism and the accusation of religious commercialism. Tourist Studies 8(2): 249-265.

Barbieri C (2010) An importance-performance analysis of the motivations behind agritourism and other farm enterprise developments in Canada. Fournal of Rural and Community Development 5(1): 1-20.

Becherer R and Helms M (2011) Is Cuba's emerging entrepreneurial economy at the crossroads? International fournal of Emerging Markets 6(4): 369-381.

Bojanic D (2011) Using a tourism importance-performance typology to investigate environmental sustainability on a global level. Fournal of Sustainable Tourism 19(8): 989-1003. 
Bonett DG and Wright TA (2000) Sample size requirements for estimating Pearson, Kendall and Spearman correlations. Psychometrika 65(1): 23-28.

Bruyere B, Rodriguez D and Vaske J (2002) Enhancing importanceperformance analysis through segmentation. Fournal of Travel $\mathcal{G}$ Tourism Marketing 12(1): 81-95.

Central de Trabajadores de Cuba (2010). Pronunciamiento de la Central de Trabajadores de Cuba. Granma. Available at: http:// www.granma.cu/espanol/cuba/13-septiembre-pronunciamiento. html.

Chomeya R (2010) Quality of psychology test between Likert scale 5 and 6 points. Fournal of Social Sciences 6(3): 399-403.

Colantonio A and Potter R (2006) City profile: Havana. Cities 23(1): 63-78.

Correia A, Oliveira N and Silva F (2009) Bridging perceived destination image and market segmentation: an application to golf tourism. European Fournal of Tourism Research 2(1): 41-69.

Cronin JJ and Taylor SA (1992) Measuring service quality: a re-examination and extension. Fournal of Marketing 56(3): $55-68$.

Echtner C and Ritchie J (1993) The measurement of destination image: An empirical assessment. Fournal of Travel Research 31(4): 3-13.

Elliott S and Neirotti LD (2008) Challenges of tourism in a dynamic island destination: the case of Cuba. Tourism Geographies 10(3): 375-402.

Enright M and Newton J (2004) Tourism destination competitiveness: A quantitative approach. Tourism Management 25(6): $777-778$.

Evans $M$ and Chon K (1989) Formulating and evaluating tourism policy using importance-performance analysis. Hospitality Education and Research Fournal 13(3): 203-213.

Fletcher M (2014). U.S. trade embargo with Cuba keeps broader economic impact at bay for now. Washington Post. Available at: http://www.washingtonpost.com/business/economy/us-trade-em bargo-with-cuba-keeps-broader-economic-impact-at-bay-fornow/2014/12/18/7d418a30-86dd-11e4-b9b7-b8632ae73d25_ story.html (accessed 2 March 2015).

Green E and Rao V (1970) Rating scales and information recovery how many scales and response categories to use? fournal of Marketing 34(3): 33-39.

Hema Nalini M and Samuel S (2011) Importance-performance analysis to determine service quality of a restaurant service an empirical study. Advances in Management 4(2): 52-57.

Henthorne T, George B and Williams A (2009) The evolving service culture of Cuban tourism: A case study. Tourismos: An International Multidisciplinary fournal of Tourism 5(2): 129-143.

Huan T, Beaman J and Shelby L (2002) Using action-grids in tourism management. Tourism Management 23: 255-264.

Hudson S, Hudson P and Miller GA (2004) The measurement of service quality in the tour operating sector: a methodological comparison. Fournal of Travel Research 42(3): 305-312.

Janes $\mathrm{P}$ and Wisnom M (2003) The use of importance performance analysis in the hospitality industry: a comparison of practices. fournal of Quality Assurance in Hospitality \& Tourism 4(1-2): 23-45.

Johns N and Howard A (1998) Customer expectations versus perceptions of service performance in the foodservice industry. International Fournal of Service Industry Management 9(3): 248-265.

Joppe M, Martin DW and Waalen J (2001) Toronto's image as a destination: a comparative importance-satisfaction analysis by origin of visitor. Fournal of Travel Research 39(3): 252.
Kim Y, Kim M and Goh B (2011) An examination of food tourist's behavior: Using the modified theory of reasoned action. Tourism Management 32(5): 1159-1165.

Kline C (2007) The role of entrepreneurial climate in rural tourism development. Unpublished dissertation completed as part of requirements for doctoral degree, North Carolina State University, USA.

Li X, Lai C, Harrill R, et al. (2011) When east meets west: An exploratory study on Chinese outbound tourists' travel expectations. Tourism Management 32(4): 741-749.

Lin Y (2009) Importance-performance analysis of the Taipei Fine Arts Museum's services. Museum Management and Curatorship 24(2): 105-121.

Loker-Murphy L and Pearce P (1995) Young budget travelers: Backpackers in Australia. Annals of Tourism Research 22(4): 819-843.

Ma E, Qu H and Njite D (2011) U.S. customer perceptions toward Chinese restaurant service quality: An importance and performance approach. Fournal of Foodservice Business Research 14(3): 290-308.

Martilla J and James J (1977) Importance-performance analysis. The fournal of Marketing 41(1): 77-79.

McArthur S (1994) Guided nature-based tourism: Separating fact from fiction. Australian Parks and Recreation 30(4): 31-36.

Mccarthy J (2006) Regeneration of cultural quarters: Public art for place image or place identity? fournal of Urban Design 11(2): 243-262.

Milne S, Ward S and Wenzel G (1995) Linking tourism and art in Canada's eastern Arctic: The case of Cape Dorset. Polar Record 31(176): 25-36.

Oh H (2001) Revisiting importance-performance analysis. Tourism Management 22(6): 617-627.

O'Leary S and Deegan J (2005) Ireland's image as a tourism destination in France: Attribute importance and performance. Fournal of Travel Research 43(3): 247-256.

Parasuraman A, Berry LL and Zeithaml VA (1988) SERVQUAL: a multiple-item scale for measuring consumer perceptions of service quality. Fournal of Retailing 64(1): 12-40.

Pearce P (1990) Farm tourism in New Zealand: A social situation analysis. Annals of Tourism Research 17(3): 337-352.

Pike S and Ryan C (2004) Destination positioning analysis through a comparison of cognitive, affective, and conative perceptions. fournal of Travel Research 42(4): 333-342.

Pritchard M and Havitz M (2006) Destination appraisal: An analysis of critical incidents. Annals of Tourism Research 33(1): 25-46.

Sánchez-Cañizares S and López-Guzmán T (2012) Gastronomy as a tourism resource: Profile of the culinary tourist. Current Issues in Tourism 15(3): 229-245.

Scher P (2011) Heritage tourism in the Carribean: The politics of culture after neoliberalism. Bulletin of Latin American Research 30(1): 7-20.

Sharpley R and Knight M (2009) Tourism and the state in Cuba: from the past to the future. International fournal of Tourism Research 11(3): 241-254.

Smith S and Costello C (2009) Culinary tourism: Satisfaction with a culinary event utilizing importance-performance grid analysis. Fournal of Vacation Marketing 15(2): 99-110.

Sörensson A and von Friedrichs Y (2013) An importance-performance analysis of sustainable tourism: A comparison between international and national tourists. Fournal of Destination Marketing \& Management 2(1): 14-21.

Sugden J (2007) Running Havana: Observations on the political economy of sport tourism in Cuba. Leisure Studies 26(2): 235-251. 
Theodoras D (2009) Customer service strategy and segmentation in food retailing using the importance-performance paradigm. Supply Chain Forum 10(2): 64-72.

Tyrrell T and Okrant M (2004) Importance-performance analysis: some recommendations from an economic planning perspective. Tourism Analysis 9: 63-76.

Zhang $\mathrm{H}$ and Chow I (2004) Application of importance-performance model in tour guides' performance: Evidence from mainland Chinese outbound visitors in Hong Kong. Tourism Management 25(1): 81-91.

\section{Author Biographies}

Carol Kline is an Associate Professor of Hospitality and Tourism Management at Appalachian State University in the Department of Management. Her research interests focus broadly on tourism planning and development and tourism sustainability but cover a range of topics such as foodie segmentation, craft beverages, agritourism, animal welfare in tourism, tourism entrepreneurship, niche tourism markets, and tourism impacts to communities.

Brian Bulla received his doctorate from the Department of Forestry and Environmental Resources at North Carolina State University in Raleigh, North Carolina. He also earned a Master of Public Administration and a Master in International Studies from NCSU. As a policy scientist, Brian researches how people conceptualize and communicate issues regarding natural resource management. Brian is particularly interested in exploring how community based participatory research can complement traditional approaches to climate change research.
Heather Rubright holds a Master of Science in Sustainable Tourism from East Carolina University and a Master of Business Administration from the University of Central Florida. She also received undergraduate degrees in Psychology and Sociology from the University of Florida. While at East Carolina, her work focused on food and tourism entrepreneurs as well as consumer decision-making in sustainable tourism. She is currently working as a consultant within the tourism industry.

Erin Green resides in Washington, DC where she is a travel advisor with McCabe World Travel, a luxury travel agency focused on customized leisure vacations all over the world. She holds a Masters degree in Sustainable Tourism from East Carolina University where her studies concentrated on culinary tourism. She also has degrees in French and environmental studies.

Erin Harris is a certified Project Management Professional (PMP) with experience working with corporations, social enterprises, nonprofits, government agencies, and small businesses. Erin's cross-sector experience has made her a systems-level, strategic thinker; she enjoys identifying creative, collaborative solutions to complex challenges. Erin uses her Master $\mathrm{s}$ in Sustainable Tourism to advance tourism as a strategy for sustainable economic development as well as provide more opportunities for people to travel regardless of their socio-economic status. Erin lives in Nashville, TN. She is the Project Manager for the Barbershop Harmony and founder of SEE Tourism. 